\title{
RADIOCARBON DATING OF SOIL ORGANIC MATTER FRACTIONS IN ANDOSOLS IN NORTHERN ECUADOR
}

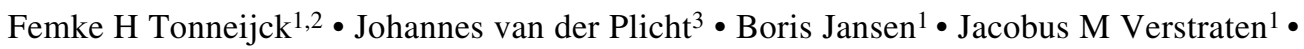 \\ Henry Hooghiemstra ${ }^{1}$
}

\begin{abstract}
Volcanic ash soils (Andosols) may offer great opportunities for paleoecological studies, as suggested by their characteristic accumulation of organic matter $(\mathrm{OM})$. However, understanding of the chronostratigraphy of soil organic matter (SOM) is required. Therefore, radiocarbon dating of SOM is necessary, but unfortunately not straightforward. Dating of fractions of SOM obtained by alkali-acid extraction is promising, but which fraction (humic acid or humin) renders the most accurate ${ }^{14} \mathrm{C}$ dates is still subject to debate. To determine which fraction should be used for ${ }^{14} \mathrm{C}$ dating of Andosols and to evaluate if the chronostratigraphy of SOM is suitable for paleoecological research, we measured ${ }^{14} \mathrm{C}$ ages of both fractions and related calibrated ages to soil depth for Andosols in northern Ecuador. We compared the time frames covered by the Andosols with those of peat sequences nearby to provide independent evidence. Humic acid (HA) was significantly older than humin, except for the mineral soil samples just beneath a forest floor (organic horizons), where the opposite was true. In peat sections, ${ }^{14} \mathrm{C}$ ages of HA and humin were equally accurate. In the soils, calibrated ages increased significantly with increasing depth. Age inversions and homogenization were not observed at the applied sampling distances. We conclude that in Andosols lacking a thick organic horizon, dating of HA renders the most accurate results, since humin was contaminated by roots. On the other hand, in mineral soil samples just beneath a forest floor, humin ages were more accurate because HA was then contaminated by younger HA illuviated from the organic horizons. Overall, the chronostratigraphy of SOM in the studied Andosols appears to be suitable for paleoecological research.
\end{abstract}

\section{INTRODUCTION}

In the Ecuadorian Andes, the rise in deforestation, grazing, and burning as a result of the increase in population pressure during the last 500 yr severely disturbed the Upper Forest Line (UFL) (Ellenberg 1979; Hofstede 1995). Therefore, the natural altitudinal position of the UFL is subject to debate (Laegaard 1992; Wille et al. 2000). In the last decade, negative impacts of deforestation were recognized and efforts made to forest degraded lands; however, forestation of tropical alpine grasslands (páramo), that under natural circumstances would not be forest, damages that ecosystem. To support sustainable forestation, we need to examine the natural dynamics of the UFL by investigating the local vegetation history.

Traditionally, vegetation history is reconstructed by analyzing fossil pollen records in peat bogs or lake sediments (e.g. Erdtman 1943; Birks and Birks 1980; Moore et al. 1991; Bradley 1999). To better understand UFL dynamics, our investigation would ideally be concentrated around the hypothetical UFL. Unfortunately, conventional polliniferous deposits are not necessarily located there.

Alternatively, Andosols, the dominant soil type in the high Andes, could provide great opportunities for paleoecological studies, including pollen analyses (Bakker and Salomons 1989). Andosols accumulate vast amounts of OM (Shoji et al. 1993), which is related to low temperatures, acidic soil pH, and the formation of organo-metallic or organo-mineral complexes that resist decomposition (Shoji et al. 1993; Torn et al. 1997). These conditions also favor pollen preservation (Moore et al. 1991), which has been demonstrated in Andosols above $3000 \mathrm{~m}$ asl in Colombia (Salomons 1986).

${ }^{1}$ ICG Centre for Geo-ecological Research, Institute for Biodiversity and Ecosystem Dynamics, University of Amsterdam, Nieuwe Achtergracht 166, 1018 WV Amsterdam, the Netherlands.

${ }^{2}$ Corresponding author. Email: f.h.tonneijck@ science.uva.nl.

${ }^{3}$ ICG Centre for Geo-ecological Research, Centre for Isotope Research, University of Groningen, the Netherlands; also Faculty of Archaeology, Leiden University, the Netherlands. 
However, to link soil pollen records to a time scale, understanding of the stratification of SOM in the soil and its age-depth relationship in particular is required (Davidson et al. 1999; Keatinge 1983). Furthermore, since pollen analysis in terrestrial soils is not a widely applied method yet, verification of the results is necessary (e.g. by comparing the pollen records from soils to those from nearby peat bogs). For such a comparison, an accurate chronology of either record is crucial. Since peat bogs and Andosols are both rich in organic carbon, measuring of radiocarbon activities offers a suitable dating method.

Unfortunately, ${ }^{14} \mathrm{C}$ dating of SOM is not straightforward (e.g. Mook and Streurman 1983; Scharpenseel and Becker-Heidmann 1992; Pessenda et al. 2001). SOM consists of a range of complex organic molecules varying in decomposition phase. The continuous input of fresh OM into soils causes the measured ${ }^{14} \mathrm{C}$ ages of bulk SOM to be somewhat younger than the depositional age (Wang et al. 1996). In addition, input of young roots into older soil horizons, leaching of mobile organic compounds through the soil profile, bioturbation, and deposition of allochtonous OM may also contaminate SOM ages (Mook and Streurman 1983; Pessenda et al. 2001). The relative importance of these pedogenetic processes, which determine the measured age of SOM, depends on soil properties and vegetation type among other factors. Therefore, interpretation of ${ }^{14} \mathrm{C}$ dates must be tailored to the specific soil ecosystem under study.

If macroremains of vegetation are lacking in the soil, dating of chemical fractions of SOM (humic substances) obtained by the standard alkali-acid extraction (Schnitzer 1982), instead of dating bulk SOM, offers the opportunity to select the fraction yielding a more accurate ${ }^{14} \mathrm{C}$ age as based on a qualitative evaluation on the validity of dating (Orlova and Panychev 1993; Kristiansen et al. 2003). However, which fraction provides the most accurate dates is not obvious. ${ }^{14} \mathrm{C}$ dating of humic substances rendered more accurate results in a range of soil types (Pessenda et al. 2001; Kovda et al. 2001; Dalsgaard and Odgaard 2001; van Mourik et al. 1995), but Andosols were not yet investigated. Dating peat bog sediments by ${ }^{14} \mathrm{C}$ analysis is generally more straightforward than dating terrestrial soils, as peat sequences are much less disturbed.

The aims of this current paper are 1) to determine which fraction of SOM (HA or humin) renders more accurate ${ }^{14} \mathrm{C}$ dates in Andosols and 2) to evaluate whether the age-depth relationship of SOM in the Andosols of our study area is suitable for paleoecological research such as the reconstruction of the natural position of the UFL. The results are compared to ${ }^{14} \mathrm{C}$ ages of similar OM fractions from nearby peat bogs, to assess whether the pollen records from those peat sequences can be used to verify the soil pollen records. By fulfilling these aims, the current paper will make an indispensable first step towards reconstruction of the UFL in northern Ecuador.

\section{DESCRIPTIVE BACKGROUND}

The study sites are located within 3 nature protection areas in northern Ecuador, near the border with Colombia (Figure 1, Table 1). The Guandera Biological Station lies in the Eastern Cordillera (mountain range) and preserves a (semi-)natural UFL at $\sim 3650 \mathrm{~m}$ asl. The transition from forest to páramo is abrupt, probably indicating at least some human influence (Laegaard 1992), but the forest still contains trees with a considerable diameter at breast height $(\mathrm{dbh})$ of $70 \mathrm{~cm}$. Some forest patches occur above the current UFL. The dominant species within the forest are Clusia flaviflora Engl., Weinmannia cochensis Hieron., and Ilex colombiana Cuatrec., and the páramo is characterized by Calamagrostis effusa Kunth (Steud.) bunch-grass and Espeletia pycnophylla Cuatrec. stem-rosette.

The El Angel Ecological Reserve and the Los Encinos Biological Station are located close to each other in the Western Cordillera and were heavily deforested before conservation; the few remaining 

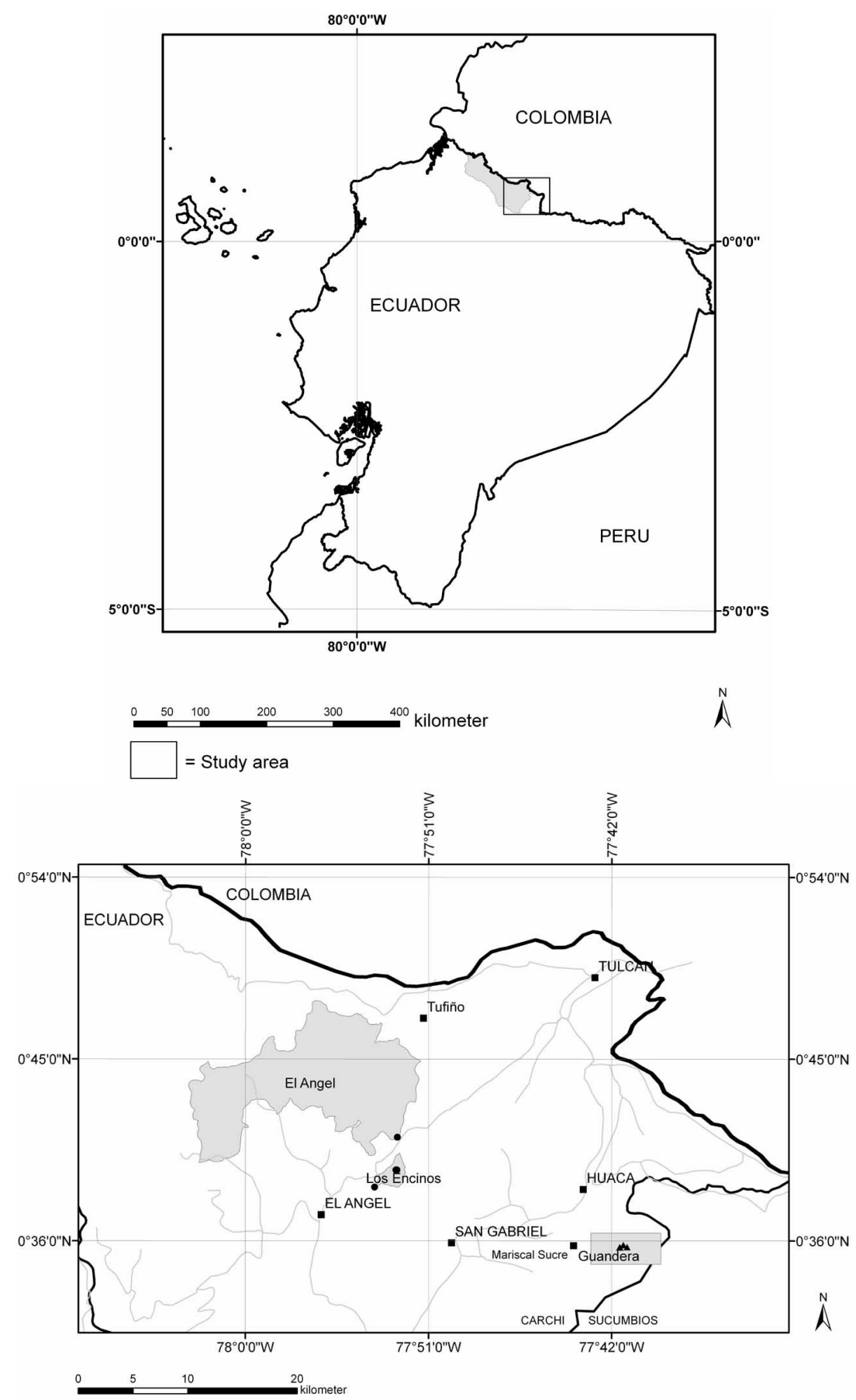

Figure 1 Maps of Ecuador (province of Carchi indicated in gray) and of the location of the National Parks (in gray) and the study sites. $\bullet=$ site of transect Western Cordillera; $\boldsymbol{\Delta}=$ site of transect Eastern Cordillera; $\mathbf{\square}=$ village or town . 
Table 1 Description of study sites.

\begin{tabular}{|c|c|c|c|c|c|}
\hline $\begin{array}{l}\text { Soil type } \\
\text { (FAO) }\end{array}$ & $\begin{array}{l}\text { Altitude } \\
\text { (m asl) }\end{array}$ & Current vegetation & Coordinates $^{\mathrm{a}}$ & Cordillera & Site \\
\hline Andosol & 3860 & Páramo & $\begin{array}{l}\mathrm{N} 0^{\circ} 35^{\prime} 48^{\prime \prime} / \\
\mathrm{W} 77^{\circ} 41^{\prime} 25^{\prime \prime}\end{array}$ & Eastern & G7 \\
\hline Andosol ${ }^{b}$ & $3697 \pm 9(n=9)$ & Forest patch in páramo & $\begin{array}{l}\text { N } 0^{\circ} 35^{\prime} 41^{\prime \prime \prime} / \\
\text { W } 77^{\circ} 41^{\prime} 36^{\prime \prime}\end{array}$ & Eastern & G5a \\
\hline Andosol & $3694 \pm 13(n=9)$ & Páramo & $\begin{array}{l}\mathrm{N} 0^{\circ} 35^{\prime} 41^{\prime \prime} / \\
\mathrm{W} 77^{\circ} 41^{\prime} 35^{\prime \prime}\end{array}$ & Eastern & $\mathrm{G} 5 \mathrm{~b}$ \\
\hline Andosol & 3570 & Forest patch in páramo & $\begin{array}{l}\text { N } 0^{\circ} 39^{\prime} 31^{\prime \prime} / \\
\text { W } 77^{\circ} 52^{\prime} 33^{\prime \prime}\end{array}$ & Western & A7A \\
\hline Andosol & 3570 & Páramo & $\begin{array}{l}\text { N } 0^{\circ} 39^{\prime} 31^{\prime \prime} / \\
\text { W } 77^{\circ} 52^{\prime} 36^{\prime \prime}\end{array}$ & Western & A7B \\
\hline Histosol & 3869 & Xyris bog & $\begin{array}{l}\text { N } 0^{\circ} 35^{\prime} 42^{\prime \prime} I \\
\text { W } 77^{\circ} 41^{\prime} 14^{\prime \prime}\end{array}$ & Eastern & G8 \\
\hline Histosol & 3740 & Oreobolus bog & $\begin{array}{l}\text { N } 0^{\circ} 41^{\prime} 16^{\prime \prime} / \\
\text { W } 77^{\circ} 52^{\prime} 46^{\prime \prime}\end{array}$ & Western & A11 \\
\hline Histosol & 3418 & Juncus bog & $\begin{array}{l}\text { N } 0^{\circ} 38^{\prime} 40^{\prime \prime} I \\
\text { W } 77^{\circ} 53^{\prime} 39^{\prime \prime}\end{array}$ & Western & $\mathrm{A} 2$ \\
\hline
\end{tabular}

${ }^{\mathrm{a}}$ GPS coordinates in WGS 1984, altitudes from altimeter, GPS altitude only used for site G8; $n=1$ unless stated otherwise. ${ }^{\mathrm{b}}$ This profile classifies as (Andic) Cambisol instead of Andosol, but since soil properties are similar to the other soils and for the purpose of simplicity, we refer to the soil as Andosol in the context of this paper.

trees rarely exceed $30 \mathrm{~cm}$ dbh. El Angel and Los Encinos are now covered with páramo vegetation and some patches of remnant forest and there is no proper UFL. However, the zonal forest patches that seem to maintain more of the original taxonomic composition of the natural montane forest are located between 3450 and $3600 \mathrm{~m}$ asl and dominated by different woody species of the genus Weinmannia and Miconia, as well as Clethra crispa C. Gust. and Hedyosmum cumbalense H. Karst. Above this altitude, the páramo vegetation is characterized again by C. effusa and E. pycnophylla.

The study area in the Eastern Cordillera receives almost double the precipitation annually than the study areas in the Western Cordillera (annual means $1900 \mathrm{~mm}$ and $1000 \mathrm{~mm}$, respectively), but mean annual temperatures are similar (from $12{ }^{\circ} \mathrm{C}$ at $3400 \mathrm{~m}$ asl to $4{ }^{\circ} \mathrm{C}$ at $4000 \mathrm{~m}$ asl). We did not observe volcanic emanations of (fossil) $\mathrm{CO}_{2}$ in the field.

In both cordilleras, we selected a forest patch and a site with páramo next to it, to determine the effect of the current vegetation on soil profile development and its SOM age-depth relationship. The floristic composition of the forest patch in Guandera is similar to that of the continuous forest belt just below the UFL, the subalpine rainforest, and similarly the forest patch in Los Encinos appears to maintain the original taxonomic composition of the now disappeared forest (Moscol et al., unpublished data). In Guandera, we additionally selected a peat bog at $3869 \mathrm{~m}$ asl and a site with páramo next to it. Furthermore, in El Angel 2 peat bogs were investigated, one at $3740 \mathrm{~m}$ asl and one at 3418 $\mathrm{m}$ asl. The El Angel peat bog at higher altitude is characterized by Oreobolus obtusangulus Gaudich and the peat of Guandera by Xyris subulata Ruiz \& Pav, both small herbs, whereas the El Angel peat bog at lower altitude is dominated by the tall rush species Juncus balticus ssp. andicola (Hook) Snogerup. The sites selected for ${ }^{14} \mathrm{C}$ dating belong to 2 transects with sites at altitudinal intervals of $100 \mathrm{~m}$ from 3000 to $4000 \mathrm{~m}$ asl. 


\section{MATERIALS AND METHODS}

\section{Sampling Procedures}

Soil pits of $\sim 1 \mathrm{~m}^{2}$ surface area and a depth of $1.5 \mathrm{~m}$ to $2 \mathrm{~m}$, depending on the soil profile, were excavated and soil profiles were described according to the guidelines for soil description of the Food and Agricultural Organization (FAO) of the United Nations (FAO 1990) and classified according to the World Reference Base (FAO 1998). In both study areas, 1 paleosol (buried soil) was generally observed beneath the current soil, indicating at least 2 main events of tephra deposition. The current soil was considered sufficiently thick to contain a period without intensive human activities. Therefore, the main focus was on the current soil profile. We took an undisturbed vertical soil sample using a metal gutter of $75 \times 5 \times 4 \mathrm{~cm}$, and if the current soil was not yet completely covered, a second vertical sample was collected with a small overlap. The gutters were packed in aluminium foil and then plastic foil and finally securely tied with adhesive tape to avoid dislocation and drying during transport. In addition, we took bulk soil samples for chemical analyses $(\sim 1 \mathrm{~kg}$ field-moist material) and ring samples (with a volume of $100 \mathrm{~cm}^{3}$ ) for bulk density determination in the same soil pit at regular depths but respecting horizon boundaries. Each bulk soil sample was obtained from a vertical interval of $\sim 5 \mathrm{~cm}$, the middle of which was noted as the depth of the sample, in order to gather sufficient material. The gutters and soil samples were stored at $2{ }^{\circ} \mathrm{C}$ under field-moist conditions prior to analyses. The peat bogs were sampled to their maximum depths with hand-operated Russian augers of 75- $\mathrm{mm}$ and 50-mm diameter and a standard length of $50 \mathrm{~cm}$ from Wittander Co. (Lund, Sweden). The smaller diameter auger is used when sediments are compact and resistant. The auger is brought to the correct depth by 1-m-long extension rods. The auger segments were wrapped in halved plastic tubes and then packed and stored like the gutter samples.

For ${ }^{14} \mathrm{C}$ dating, at least 3 samples per soil profile were cored from the gutter samples using a corer with $0.5-\mathrm{cm}$ diameter to minimize the time span covered by the sample. Two samples were located in the current soil: one just below the mineral soil surface in the Ah horizon and one at its bottom in the Ah2 or Bw horizon. A third sample was taken at the top of the paleosol, the 2Ahb horizon. Additionally, we took 2 samples from the thick organic horizon in the Guandera forest profile (one in the middle and one at the boundary with the Ah horizon) and one extra sample at the top of the páramo soil profile located next to it. The vertical distance between samples was on average $40 \mathrm{~cm}$. The samples for ${ }^{14} \mathrm{C}$ dating were taken at the same depths as the samples for chemical analyses (except for the sample at the boundary between organic horizon and $\mathrm{Ah}$ ). In the peat cores, 3 samples at regular spacing were taken using the same 0.5 -cm-diameter corer. Fresh roots were removed from the peat sample by hand-picking using a binocular.

\section{Laboratory Procedures}

Chemical fractionation of SOM by alkali-acid extraction followed the procedure of Schnitzer (1982), which is the conventional method for OM fractionation (Stevenson 1994). The organic fraction that is soluble in alkali solution and immobile in acid solution is called HA; the residual fraction (immobile in both alkali solution and acid solution) is referred to as humin. Fulvic acid, the OM fraction that is soluble in both alkali solution and acid solution, was discarded because of its inherent mobility in soils. Humin is generally considered to be the most humified (decomposed) OM fraction. Strictly speaking, the division of OM in humic substances is not meaningful in the case of peat, since decomposition is negligible and consequently the composition of $\mathrm{OM}$ in peat is not much altered. However, for a proper comparison of soil and peat records we fractionated the peat samples as well, applying the same procedure. 
Soil $\mathrm{pH}$ was measured with a glass electrode (Consort SP10B, Turnhout, Belgium) in a $0.01 \mathrm{M} \mathrm{CaCl}_{2}$ soil solution (w/v 1:5 mineral soil samples and w/v 1:10 organic samples, using field-moist samples) as a measure of actual acidity. Total carbon was measured with a VarioEL (Elementar Analysensysteme $\mathrm{GmbH}$, Hanau, Germany) CNS auto-analyzer. Total carbon equals organic carbon, since carbonates are not present. Dry bulk density was determined by weighing oven-dried samples $\left(105^{\circ} \mathrm{C}\right.$, 44-hr mineral soil samples and $70{ }^{\circ} \mathrm{C}, 48$-hr organic samples) and then dividing the oven-dry weight by the known volume of the sampling ring $\left(100 \mathrm{~cm}^{3}\right)$.

\section{Radiocarbon Dating}

${ }^{14} \mathrm{C}$ analysis was performed by the accelerator mass spectrometry (AMS) facility of Groningen University, the Netherlands (laboratory code GrA). AMS enables the measurement of ${ }^{14} \mathrm{C}$ concentrations in graphite made from milligram-size sample material. After pretreatment as described above, the isolated fraction of the original sample is combusted into $\mathrm{CO}_{2}$ and purified using an elemental analyzer (EA) (Aerts et al. 2001). The EA provides also quality check parameters such as the organic carbon content and the $\delta^{13} \mathrm{C}$ value of the sample. The $\mathrm{CO}_{2}$ is then collected cryogenically for later graphitization. The graphite powder is pressed into targets that are placed in the sample carousel of ion source of the AMS. The AMS system measures the isotopic ratios ${ }^{14} \mathrm{C} /{ }^{12} \mathrm{C}$ and ${ }^{13} \mathrm{C} /{ }^{12} \mathrm{C}$ of the graphite (van der Plicht et al. 2000). Typical measurement errors are 0.4\% (Meijer et al. 2006). From these measured isotopic ratios, the ${ }^{14} \mathrm{C}$ activities are calculated (including the correction for isotopic fractionation) and the ${ }^{14} \mathrm{C}$ ages are given in $\mathrm{BP}$.

Telford et al. (2004) explained that mathematical age-depth relationships only make sense when using calibrated ${ }^{14} \mathrm{C}$ ages. Therefore, to evaluate the $\mathrm{OM}$ age-depth relationship for the soil and peat sequences, we transformed ${ }^{14} \mathrm{C}$ ages to a calendar year probability distribution (cal $\mathrm{AD} / \mathrm{BC}$ ) with the WinCal25 calibration software (van der Plicht 2005) using the presently recommended IntCal04 calibration data set (Reimer et al. 2004). Some ${ }^{14} \mathrm{C}$ measurements yield activities $>100 \%$, which means the samples are modern, containing ${ }^{14} \mathrm{C}$ above the natural level, produced by atmospheric nuclear explosions during the late 1950s and early 1960s - the so-called "bomb peak." The atmospheric ${ }^{14} \mathrm{C}$ content for these "modern samples" is derived from direct measurements of ${ }^{14} \mathrm{C}$ in atmospheric $\mathrm{CO}_{2}$, for a variety of locations (e.g. New Zealand: Manning et al. 1990; Norway: Nydal and Lövseth 1983; the Netherlands: Meijer et al. 1995). These records can be used to transfer the ${ }^{14} \mathrm{C}$ activities to calendar ages. Our data contain just a few such modern measurements; since our measurements are within the error, it is not relevant which of these atmospheric data sets are used for our purposes.

Calibrated ${ }^{14} \mathrm{C}$ ages are expressed as the range of calendar years of the $1-\sigma$ peak with the largest relative area under the probability distribution, except for the modern samples where the most probable range was selected based on expert knowledge. Since the ranges are small, calculations are performed with the mean and the dots displayed in the graphs represent the whole range of calendar years at the scale of the graph.

\section{Statistical Analysis}

Differences in means were considered significant when $p<0.01$ unless stated otherwise, as determined with a 2-tailed paired-samples test performed with the SPSS Compare Means procedure (SPSS Inc. 2001). Pearson's correlations (bivariate) between variables were calculated using the SPSS Correlate procedure and considered significant when $p<0.01$ unless stated otherwise. We performed a linear regression in Graphpad Prism (Graphpad Software Inc. 1999) to evaluate the relationship between calibrated age and depth. 


\section{RESULTS AND DISCUSSION}

Soil properties are reported in Table 2. The soils in both areas consist of Andosols (FAO 1998) with upper mineral horizons characterized by a very large organic carbon content (9-21\%), acidic $\mathrm{pH}$ ( $\mathrm{pH} \mathrm{CaCl}_{2} 3.7$ to 4.5 ), and low dry bulk densities $\left(0.4-0.6 \mathrm{~g} \mathrm{~cm}^{-3}\right.$ ). The dry bulk densities are similar for all samples and therefore the effect of compaction on the age-depth relationship as described by Hetier et al. (1983) is minimal. The horizon sequence can be summarized as Ah1 - Ah2/Bw - 2Ahb - 2Bwsb - 2BCb, common for Andosols (Shoji et al. 1993). The forest profiles in addition have organic horizons (a forest floor) overlying the mineral horizons. All soils show a multisequum, containing at least 1 paleosol. Roots concentrate in the first Ah horizon of the páramo soils and in the relatively nutrient-rich organic horizons of the forest soils.

\section{${ }^{14} \mathrm{C}$ Ages of HA and Humin in Andosols}

The results of ${ }^{14} \mathrm{C}$ dating of the HA and humin fraction of soils collected in the Eastern and Western cordilleras of northern Ecuador are presented in Table 3 and Figure 2. The $\delta^{13} \mathrm{C}$ values (Table 3) indicate a dominant $\mathrm{C} 3$ vegetation, which is to be expected in a humid, cold climate. Humic acid and humin contributed equal proportions (both $\sim 30 \%$ organic carbon, data not shown) to the total bulk soil organic carbon, underlining that the impact of contamination of either fraction on bulk SOM age will be considerable.

The HA fraction was significantly $(p=0.001)$ older than the humin fraction, except for the mineral soil samples just beneath a forest floor, where the opposite was found. The difference between the ${ }^{14} \mathrm{C}$ ages of the fractions (hereafter referred to as "age difference") can be used as a measure of contamination with younger material (e.g. by roots). The absolute age difference ranges from $33{ }^{14} \mathrm{C} \mathrm{yr}$ to $995{ }^{14} \mathrm{C}$ yr and increases significantly with increasing ${ }^{14} \mathrm{C}$ age $\left(r=+0.85, p=0.000\right.$ with ${ }^{14} \mathrm{C}$ age $\mathrm{HA}$ and $r=+0.79, p=0.001$ with ${ }^{14} \mathrm{C}$ age humin; mineral soil samples just beneath a forest floor excluded). The ${ }^{14} \mathrm{C}$ age increases significantly with depth for both fractions $\left(r=+0.93\right.$ with ${ }^{14} \mathrm{C}$ age $\mathrm{HA}$ and +0.94 with ${ }^{14} \mathrm{C}$ age humin, both with $p=0.000$, modern samples excluded).

Contamination with roots may well explain the observed younger ${ }^{14} \mathrm{C}$ ages of humin. Although the humin fraction is often considered as the OM fraction containing the most resistant and immobile organic molecules (Pessenda et al. 2001; Stevenson 1994), some authors report that it is also the fraction that is rejuvenated considerably by the inclusion of relatively young roots (Orlova and Panychev 1993). In accordance, Nierop et al. (1999) and Nierop and Buurman (1999) demonstrated with pyrolysis-gas chromatography/mass spectrometry (GC/MS) that organic molecules of fresh roots accumulate in the humin fraction. The larger age differences with older ${ }^{14} \mathrm{C}$ ages may be explained by the prolonged exposure to contamination by roots. Additionally, the rejuvenating impact of fresh roots is higher on samples with low ${ }^{14} \mathrm{C}$ activity than on samples with high ${ }^{14} \mathrm{C}$ activity (Mook and van de Plassche 1986).

However, how accurate are the ${ }^{14} \mathrm{C}$ ages of the $\mathrm{HA}$ fractions? It is highly unlikely that HA is mobile in the mineral part of Andosols because of the high metal/SOM ratio combined with the very low $\mathrm{pH}$ in these soils. Therefore, contamination by illuviation of younger HA is negligible. In addition, undisturbed Andosols show strong resistance to water erosion due to rapid rainfall infiltration and high aggregate resistance to dispersion (Shoji et al. 1993). In the field, we did not observe signs of erosion or deposition on our sites. Hence, deposition of allochtonous OM is not expected to have a dominant influence. Some earthworm species are known to burrow up to $1 \mathrm{~m}$ depth (Lee and Foster 1991) and Barois et al. (1998) observed earthworm casts up to $60 \mathrm{~cm}$ depth in Mexican Andosols at $3100 \mathrm{~m}$ asl (mean annual temperature $5-10^{\circ} \mathrm{C}$ and $\mathrm{pH} \mathrm{KCl}$ at $20 \mathrm{~cm}$ soil depth $=4.6$ ). However, the 
Table 2 Selected soil properties for the Andosols (mean and standard deviations calculated if at least 2 samples were taken within the horizon at different depths).

\begin{tabular}{|c|c|c|c|c|c|c|}
\hline Site & Horizon $^{\mathrm{a}}$ & $\begin{array}{l}\text { Depth } \\
(\mathrm{cm})\end{array}$ & $\begin{array}{l}\text { Bulk density } \\
\left(\mathrm{g} \mathrm{cm}^{-3}\right)\end{array}$ & $\begin{array}{l}\mathrm{C}_{\text {total }} \\
(\%)\end{array}$ & $\mathrm{pH} \mathrm{CaCl}{ }_{2}$ & Roots $^{b}$ \\
\hline \multirow[t]{7}{*}{ G7 } & $\mathrm{O}$ & $0-1$ & n.d. & n.d. & 4.4 & n.d. \\
\hline & Ah1 & $1-40$ & 0.35 & $18.20 \pm 2.7$ & $4.0 \pm 0.1$ & common v.f., few f., very few m. \\
\hline & Ah2 & $40-70$ & $0.42 \pm 0.0$ & $13.07 \pm 0.6$ & $4.3 \pm 0.0$ & few v.f., very few f. \\
\hline & 2Ahb & $70-130$ & $0.36 \pm 0.0$ & $17.62 \pm 2.9$ & $4.2 \pm 0.1$ & few v.f., very few f. \\
\hline & $2 \mathrm{Bw} 1 \mathrm{~b}$ & $130-147$ & 0.71 & 5.30 & 4.6 & few v.f., very few f. \\
\hline & $2 \mathrm{Bws} 2 \mathrm{~b}$ & $147-150$ & n.d. & n.d. & n.d. & n.o. \\
\hline & $2 \mathrm{BC} 3 \mathrm{~b}$ & $150-170+$ & 0.93 & 0.38 & 5.4 & n.o. \\
\hline \multirow[t]{9}{*}{ G5a } & $\mathrm{O} 1$ & $0-1$ & n.d. & n.d. & 3.9 & n.d. \\
\hline & $\mathbf{O 2}$ & $1-35$ & 0.10 & $50.11 \pm 0.2$ & $2.5 \pm 0.1$ & common v.f. to f., few m., very few c. \\
\hline & $\mathbf{A h}$ & $35-75$ & $0.45 \pm 0.0$ & $15.58 \pm 3.0$ & $3.9 \pm 0.3$ & very few v.f. to c. \\
\hline & Bw & $75-105$ & $0.57 \pm 0.0$ & $9.51 \pm 0.9$ & $4.2 \pm 0.0$ & very few v.f. to $\mathrm{m}$. \\
\hline & 2Ah1b & $105-125$ & 0.48 & 13.34 & 4.1 & very few v.f. to $f$. \\
\hline & $2 \mathrm{Ah} 2 \mathrm{~b}$ & $125-140$ & 0.44 & 12.46 & 4.1 & very few v.f. to f. \\
\hline & $2 \mathrm{Ah} 3 \mathrm{~b}$ & $140-175$ & 0.42 & 12.01 & 4.3 & very few v.f. to f. \\
\hline & 2Bsw1b & $175-177$ & n.d. & n.d. & n.d. & n.o. \\
\hline & $2 \mathrm{BC} 2 \mathrm{~b}$ & $177-190+$ & 0.92 & 0.35 & 5.1 & n.o. \\
\hline \multirow[t]{8}{*}{ G5b } & $\mathrm{O}$ & $0-1$ & n.d. & n.d. & 4.1 & n.d. \\
\hline & Ah & $1-45$ & $0.37 \pm 0.1$ & $17.71 \pm 3.7$ & $4.1 \pm 0.2$ & common v.f., few f., very few m. to c. \\
\hline & Bw1 & $45-70$ & 0.54 & 9.15 & 4.4 & few v.f., very few f. \\
\hline & Bw2 & $70-115$ & $0.57 \pm 0.0$ & $8.48 \pm 0.6$ & $4.4 \pm 0.0$ & few v.f., very few f. \\
\hline & 2Ahb & $115-175$ & $0.48 \pm 0.1$ & $10.92 \pm 1.0$ & $4.3 \pm 0.1$ & very few v.f. to $f$. \\
\hline & $2 \mathrm{Bw} 1 \mathrm{~b}$ & $175-192$ & 0.61 & 7.13 & 4.6 & n.d. \\
\hline & $2 \mathrm{Bws} 2 \mathrm{~b}$ & 192-194 & n.d. & n.d. & n.d. & n.o. \\
\hline & $2 \mathrm{BC} 3 \mathrm{~b}$ & $194-200+$ & 0.94 & 0.29 & 5.2 & n.o. \\
\hline \multirow[t]{7}{*}{$\mathrm{A} 7 \mathrm{a}$} & $\mathrm{O} 1$ & $0-1$ & n.d. & n.d. & 3.8 & n.d. \\
\hline & $\mathrm{O} 2$ & $1-5$ & n.d & 42.87 & 3.7 & many v.f. to f., common m., very few c. \\
\hline & Ah1 & $5-40$ & $0.42 \pm 0.1$ & $20.21 \pm 6.6$ & $3.7 \pm 0.4$ & few v.f. to f., very few m. \\
\hline & Ah2 & $40-80$ & $0.51 \pm 0.1$ & $9.45 \pm 2.1$ & $4.2 \pm 0.1$ & few v.f. to f., very few m. \\
\hline & 2Ahb & $80-165$ & $0.41 \pm 0.0$ & $13.90 \pm 2.1$ & $4.2 \pm 0.1$ & very few v.f. to f. \\
\hline & $2 \mathrm{ABb}$ & $165-175$ & 0.66 & 5.60 & 4.5 & n.o. \\
\hline & $2 \mathrm{BCb}$ & $175-195+$ & 0.97 & 0.70 & 5.2 & n.o. \\
\hline \multirow[t]{6}{*}{$\mathrm{A} 7 \mathrm{~b}$} & $\mathrm{O}$ & $0-1$ & n.d. & n.d. & 4.6 & n.d. \\
\hline & Ah1 & $1-25$ & 0.43 & 16.97 & 4.1 & common v.f. to f., few m., very few c. \\
\hline & Ah2 & $25-70$ & $0.52 \pm 0.1$ & $9.21 \pm 1.6$ & $4.5 \pm 0.1$ & few v.f. to f. and very few m. \\
\hline & 2Ahb & $70-135$ & $0.40 \pm 0.0$ & $14.61 \pm 2.1$ & $4.3 \pm 0.0$ & few v.f. to f. and very few m. \\
\hline & $2 \mathrm{ABb}$ & $135-155$ & 0.66 & 6.43 & 4.7 & very few v.f. to f. \\
\hline & $2 \mathrm{BCb}$ & $155-177$ & 0.99 & 0.78 & 5.2 & n.o. \\
\hline
\end{tabular}

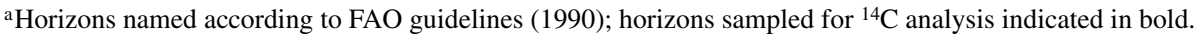

${ }^{\mathrm{b}}$ As described in the field according to FAO guidelines (1990): v.f. = very fine roots; $\mathrm{f}$. = fine roots; $\mathrm{m}$. = medium roots; c. $=$ coarse roots; n.d. = not determined; n.o. $=$ not observed. 
Table $3{ }^{14} \mathrm{C}$ ages (BP) and ${ }^{13} \mathrm{C}(\%)$ values of $\mathrm{HA}$ and humin in the Andosols.

\begin{tabular}{|c|c|c|c|c|c|c|c|c|}
\hline \multirow[b]{2}{*}{ Site } & \multirow[b]{2}{*}{ Horizon } & \multirow[b]{2}{*}{$\begin{array}{l}\text { Sample } \\
\text { depth }(\mathrm{cm})\end{array}$} & \multicolumn{3}{|c|}{ Humic acid } & \multicolumn{3}{|c|}{ Humin } \\
\hline & & & $\begin{array}{l}\text { CIO code } \\
\text { GrA- }\end{array}$ & $\begin{array}{l}{ }^{14} \mathrm{C} \text { age }^{\mathrm{a}} \\
(\mathrm{BP})\end{array}$ & $\begin{array}{l}{ }^{13} \mathrm{C} \\
(\% o)\end{array}$ & $\begin{array}{l}\text { CIO code } \\
\text { GrA- }\end{array}$ & $\begin{array}{l}{ }^{14} \mathrm{C} \text { age }^{\mathrm{a}} \\
(\mathrm{BP})\end{array}$ & $\begin{array}{l}{ }^{13} \mathrm{C} \\
(\% o)\end{array}$ \\
\hline G7 & Ah1 & $10.0-10.5$ & 28130 & $180 \pm 35$ & -25.24 & 28117 & $45 \pm 35$ & -25.67 \\
\hline G7 & Ah2 & $46.5-47.0$ & 28134 & $1690 \pm 40$ & -25.22 & 28131 & $1405 \pm 35$ & -25.66 \\
\hline G7 & $2 \mathrm{Ahb}$ & $89.5-90.0$ & 28126 & $4910 \pm 45$ & -24.98 & 28135 & $4130 \pm 40$ & -25.47 \\
\hline G5a & $\mathrm{F}$ & $14.5-15.0$ & 30109 & $\begin{array}{l}-623 \pm 35 \\
(108.1 \pm 0.4)\end{array}$ & -27.46 & 30108 & $\begin{array}{l}-656 \pm 35 \\
(108.5 \pm 0.4)\end{array}$ & -28.83 \\
\hline G5a & $\mathrm{F}$ & $34.0-34.5$ & 30112 & $\begin{array}{c}-28 \pm 35 \\
(100.4 \pm 0.4)\end{array}$ & -26.39 & 30110 & $\begin{array}{l}-218 \pm 35 \\
(102.8 \pm 0.4)\end{array}$ & -26.93 \\
\hline G5a & $\mathrm{Ah}$ & $45.0-45.5$ & 28102 & $490 \pm 35$ & -25.67 & 28101 & $775 \pm 35$ & -25.93 \\
\hline G5a & $\mathrm{Bw}$ & $84.5-85.0$ & 28104 & $2170 \pm 35$ & -25.92 & 28103 & $2005 \pm 35$ & -26.56 \\
\hline G5a & $2 \mathrm{Ah} 1 \mathrm{~b}$ & $114.5-115.0$ & 28108 & $4355 \pm 40$ & -25.10 & 28106 & $3360 \pm 35$ & -26.13 \\
\hline G5b & $\mathrm{Ah}$ & $14.5-15.0$ & 30138 & $590 \pm 35$ & -25.33 & 30136 & $425 \pm 35$ & -25.69 \\
\hline G5b & $\mathrm{Ah}$ & $34.5-35.0$ & 28111 & $1350 \pm 35$ & -25.45 & 28109 & $1270 \pm 35$ & -26.08 \\
\hline G5b & Bw2 & $75.0-75.5$ & 28113 & $3465 \pm 35$ & -25.51 & 28112 & $2615 \pm 35$ & -26.09 \\
\hline G5b & $2 \mathrm{Ahb}$ & $124.5-125.0$ & 28116 & $5730 \pm 40$ & -24.91 & 28115 & $4945 \pm 40$ & -25.16 \\
\hline $\mathrm{A} 7 \mathrm{a}$ & Ah1 & $30.0-30.5$ & 28129 & $445 \pm 35$ & -26.08 & 28127 & $555 \pm 35$ & -25.95 \\
\hline $\mathrm{A} 7 \mathrm{a}$ & Ah2 & $64.5-65.0$ & 30153 & $2050 \pm 35$ & -25.24 & 30154 & $1505 \pm 35$ & -24.94 \\
\hline $\mathrm{A} 7 \mathrm{a}$ & $2 \mathrm{Ahb}$ & $99.5-100.0$ & 28140 & $4715 \pm 40$ & -24.17 & 28139 & $3930 \pm 40$ & -24.56 \\
\hline$A 7 b$ & Ah1 & $15.0-15.5$ & 28144 & $595 \pm 35$ & -24.68 & 28141 & $310 \pm 35$ & -25.02 \\
\hline$A 7 b$ & Ah2 & $54.5-55.0$ & 28146 & $2540 \pm 40$ & -25.15 & 28145 & $2320 \pm 35$ & -25.60 \\
\hline$A 7 b$ & $2 \mathrm{Ahb}$ & $85.0-85.5$ & 28149 & $4060 \pm 45$ & -24.55 & 28147 & $3470 \pm 40$ & -24.95 \\
\hline
\end{tabular}

aFor samples with measured activities higher than the standard, the ${ }^{14} \mathrm{C}$ ages expressed in $\mathrm{BP}$ are negative numbers. In these cases, we also show the activity ratios in \%.

strong correlation between age and depth in the studied soils indicates that bioturbation did not homogenize SOM at the scale of the applied vertical sampling distances. We thus conclude that the ${ }^{14} \mathrm{C}$ ages of the HA fractions are more accurate than the ${ }^{14} \mathrm{C}$ ages of the humin fractions for all samples except the mineral soil samples just beneath a forest floor.

Two factors may explain the younger ${ }^{14} \mathrm{C}$ age of $\mathrm{HA}$ compared to that of humin in the mineral soil samples just beneath a forest floor. Firstly, contrary to the mineral horizons, HA may be mobile in the organic horizons overlying them in the forest. Upon entering the mineral horizon these younger mobile HA form complexes with the abundant metals in Andosols ( $\mathrm{Al}$ and $\mathrm{Fe}$ ) and become immobile. Consequently, the ${ }^{14} \mathrm{C}$ age of the HA fraction in that mineral topsoil is lowered. Secondly, roots concentrate in the relatively nutrient-rich organic horizons rather than in the mineral horizons (Table 2), resulting in less contamination of the humin fraction of the mineral horizon. Accordingly, in the organic horizon, HA was again older than or of equal age as humin. Possibly, mobile (younger) HA disappears from the organic horizons by leaching while the residual HA remains immobile and uncontaminated. We therefore conclude that in the mineral soil samples just beneath a forest floor, the humin fraction is more accurate for dating, if roots are removed adequately. In the organic horizons themselves, HA still seems more accurate for dating, but more data is necessary to support this conclusion.

Páramo fires are common in the northern Andes (Ramsay and Oxley 1996; Hofstede 1995; Laegaard 1992), and they may occur even in protected areas. Fire can cause complex transformations within the humic substances, e.g. from FA to HA and from HA to humin and black carbon (Gonzalez-Perez et al. 2004). Since the original humic substances may differ in ${ }^{14} \mathrm{C}$ age, such fire-induced 

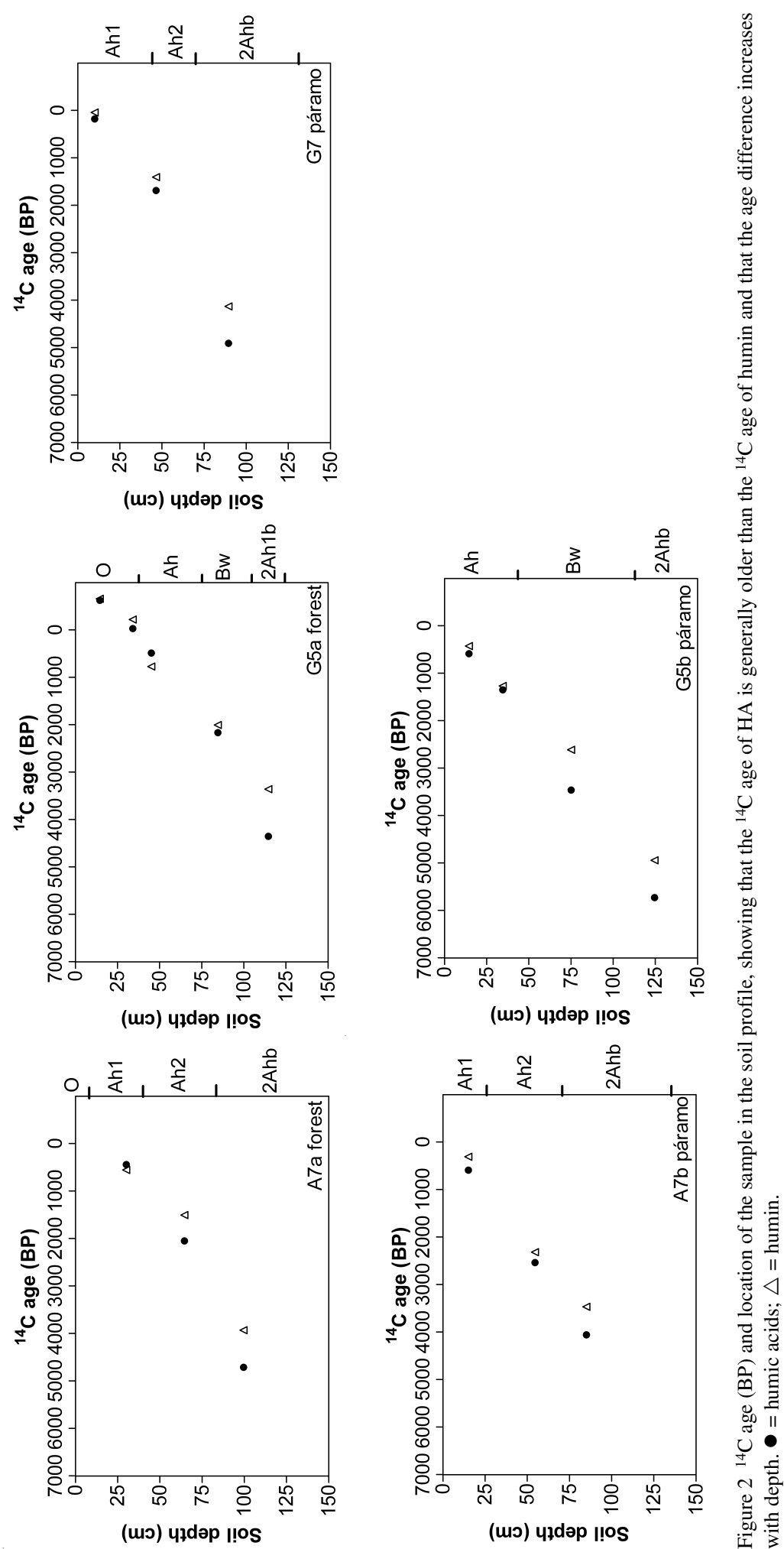
transformations could contaminate the measured ${ }^{14} \mathrm{C}$ age of a specific $\mathrm{OM}$ fraction. However, transitions due to fire are much less if OM is complexed with metals or minerals (Gonzalez-Perez et al. 2004) as is the case in Andosols. Furthermore, during a páramo fire, soil temperatures $2 \mathrm{~cm}$ below ground remain relatively low, not exceeding $65^{\circ} \mathrm{C}$ (Ramsay and Oxley 1996), making such transitions unlikely (Gonzalez-Perez et al. 2004). Therefore, we regard the contaminating effect of fire on ${ }^{14} \mathrm{C}$ age as minimal.

Our results show that both $\mathrm{HA}$ and humin can be used for ${ }^{14} \mathrm{C}$ dating, but the accuracy of either depends on, for example, soil properties and vegetation type, stressing the necessity for tailor-made research. Additionally, the ${ }^{14} \mathrm{C}$ ages of both $\mathrm{HA}$ and humin remain an average, influenced by the continuous input of fresh OM (Wang et al. 1996), and must thus be interpreted as minimum ages.

\section{${ }^{14} \mathrm{C}$ Ages of HA and Humin in Peat}

The results of ${ }^{14} \mathrm{C}$ dating of the $\mathrm{HA}$ and humin fraction of peat, collected in the Eastern and Western cordilleras of northern Ecuador, are presented in Table 4 . The $\delta^{13} \mathrm{C}$ values in Table 4 are those of a $\mathrm{C} 3$ vegetation, which is to be expected in peat.

Table $4{ }^{14} \mathrm{C}$ ages (BP) and ${ }^{13} \mathrm{C}(\%)$ values of $\mathrm{HA}$ and humin of the peat sequences.

\begin{tabular}{lllll|lll}
\hline & & \multicolumn{3}{c|}{ Humic acid } & \multicolumn{3}{c}{ Humin } \\
\cline { 3 - 8 } & Sample depth & CIO code & ${ }^{14} \mathrm{C}$ age & ${ }^{13} \mathrm{C}$ & CIO code & ${ }^{14} \mathrm{C}$ age & ${ }^{13} \mathrm{C}$ \\
Site & $(\mathrm{cm})$ & GrA- & \multicolumn{1}{l}{ (BP) } & $(\% \circ)$ & GrA- & $(\mathrm{BP})$ & $(\% \circ)$ \\
\hline G8 & $146.0-147.0$ & 28093 & $2110 \pm 35$ & -25.19 & 28092 & $2110 \pm 35$ & -25.30 \\
G8 & $196.0-197.0$ & 28097 & $6075 \pm 40$ & -24.95 & 28095 & $5980 \pm 40$ & -25.11 \\
G8 & $246.0-247.0$ & 28099 & $8010 \pm 50$ & -25.06 & 28098 & $8290 \pm 50$ & -24.92 \\
A11 & $100.0-101.0$ & 28057 & $1640 \pm 35$ & -26.20 & 28055 & $1610 \pm 35$ & -26.33 \\
A11 & $160.0-161.0$ & 28059 & $3450 \pm 35$ & -26.06 & 28058 & $3330 \pm 35$ & -26.21 \\
A11 & $222.0-222.5$ & 28082 & $7515 \pm 45$ & -26.53 & 28081 & $7625 \pm 45$ & -26.89 \\
A2 & $66.0-66.5$ & 28086 & $290 \pm 35$ & -26.96 & 28083 & $185 \pm 35$ & -26.46 \\
A2 & $176.5-177.0$ & 28088 & $1500 \pm 35$ & -27.42 & 28087 & $1525 \pm 35$ & -26.58 \\
A2 & $290.0-290.5$ & 28091 & $2630 \pm 35$ & -26.78 & 28089 & $2940 \pm 35$ & -26.46 \\
\hline
\end{tabular}

Contrary to the soils, the difference between the ${ }^{14} \mathrm{C}$ ages of $\mathrm{HA}$ and that of humin is generally small and not significant $(p=0.459)$, although Shore et al. (1995) demonstrated that large age differences (up to $1210{ }^{14} \mathrm{C}$ yr) between these fractions can exist in peat samples. Several factors explain the similarity in ${ }^{14} \mathrm{C}$ ages of the humic substances in peat. Firstly, bioturbation is of minor importance. Secondly, the time span of contamination with roots is limited due to the continuous shifting upwards of the active rooting zone during OM accumulation (peat growth). Additionally, the depth of the top samples (varying from $60 \mathrm{~cm}$ to $150 \mathrm{~cm}$ ) is probably already beyond the currently active rooting zone. Finally, although HA mobility cannot be ruled out, its vertical movement may be limited in stagnant water.

Only in 2 cases (GrA-28099 and -28091) was the age difference somewhat larger, the differences amounting to 310 and $280{ }^{14} \mathrm{C} \mathrm{yr}$, respectively, and humin rendering older ages. These age differences are small compared to the differences occurring in the soils (differences up to $995{ }^{14} \mathrm{C}$ yr) as well as compared to the differences reported by Shore et al. (1995) for peat sequences (differences up to $1210{ }^{14} \mathrm{C}$ yr). Currently, we have no information on the basis of which we can explain the somewhat larger differences for the 2 samples; therefore, we treat our samples as 1 statistical population and regard the differences as not significant. 
Our results show that ${ }^{14} \mathrm{C}$ ages of both HA and humin are equally accurate for the peat bogs, although ages are still averages and should be interpreted as a minimum (Wang et al. 1996). However, in the active rooting zone the humin ages may become less accurate due to contamination by fresh roots.

\section{SOM Age-Depth Relationship in Andosols}

To evaluate if the chronostratigraphy of SOM in the studied Andosols is suitable for paleoecological research such as the reconstruction of the natural UFL, we investigated the relationship between age and depth. Calibrated ${ }^{14} \mathrm{C}$ ages and depth are shown in Table 5. We used the calibrated ${ }^{14} \mathrm{C}$ ages of $\mathrm{HA}$ for the age-depth relationship in all cases, except for the mineral soil samples just beneath a forest floor, where we used calibrated ${ }^{14} \mathrm{C}$ ages of humin instead. There are no age inversions and no signs of homogenization at the applied sampling distances (see Table 5).

Table 5 Calibrated ${ }^{14} \mathrm{C}$ ages (range and mean, year $\mathrm{AD} / \mathrm{BC}$ ) of the Andosols.

\begin{tabular}{llclll}
\hline & & & \multicolumn{2}{c}{ Calibrated age $^{\mathrm{a}}$} \\
\cline { 4 - 5 } Site & Horizon & $\begin{array}{l}\text { Sample depth } \\
\text { (cm) }\end{array}$ & $\begin{array}{l}\text { Range } \\
\text { (cal AD/BC) }\end{array}$ & $\begin{array}{l}\text { Mean } \\
\text { (cal AD/BC) }\end{array}$ \\
\hline G7 & Ah1 & $10.0-10.5$ & cal AD 1761-1789 & cal AD 1775 \\
G7 & Ah2 & $46.5-47.0$ & cal AD 329-407 & cal AD 368 \\
G7 & 2Ahb & $89.5-90.0$ & cal BC 3712-3643 & cal BC 3678 \\
G5a & F & $14.5-15.0$ & cal AD 1996-2002 & cal AD 1999 \\
G5a & F & $34.0-34.5$ & cal AD 1956-1957 & cal AD 1957 \\
G5a & Ah & $45.0-45.5$ & cal AD 1247-1271 & cal AD 1259 \\
G5a & Bw & $84.5-85.0$ & cal BC 352-293 & cal BC 323 \\
G5a & 2Ah1b & $114.5-115.0$ & cal BC 3015-2944 & cal BC 2980 \\
G5b & Ah & $14.5-15.0$ & cal AD 1311-1359 & cal AD 1335 \\
G5b & Ah & $34.5-35.0$ & cal AD 648-682 & cal AD 665 \\
G5b & Bw2 & $75.0-75.5$ & cal BC 1780-1740 & cal BC 1760 \\
G5b & 2Ahb & $124.5-125.0$ & cal BC 4614-4515 & cal BC 4565 \\
A7a & Ah1 & $30.0-30.5$ & cal AD 1392-1418 & cal AD 1405 \\
A7a & Ah2 & $64.5-65.0$ & cal BC 105-29 & cal BC 67 \\
A7a & 2Ahb & $99.5-100.0$ & cal BC 3430-3378 & cal BC 3404 \\
A7b & Ah1 & $15.0-15.5$ & cal AD 1309-1361 & cal AD 1335 \\
A7b & Ah2 & $54.5-55.0$ & cal BC 797-760 & cal BC 779 \\
A7b & 2Ahb & $85.0-85.5$ & cal BC 2634-2562 & cal BC 2598 \\
\hline
\end{tabular}

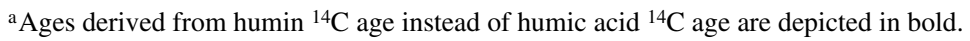

Since we measured only a few samples per soil profile, we performed linear regressions on the relationship between calibrated age and depth for all soils grouped together, for the soils grouped according to cordillera (Eastern or Western), and for the soils grouped according to current vegetation type (forest or páramo). Therefore, our linear regressions cannot be used to interpolate dates in between measured dates for a given soil profile. However, they can be used to evaluate whether rates of SOM accumulation differ between the cordilleras and between current vegetation types. Shoji et al. (1993) stressed the influence of vegetation on Andosol formation. Results of all linear regressions are presented in Table 6 and the linear regressions according to cordillera are additionally shown in Figure 3. Because of the different nature of the forest floor, we excluded the organic sam- 
ples from the regressions, but the samples are included in the figures. All these linear regressions have a good fit $\left(R^{2} \geq 0.85\right)$ and a narrow confidence interval (CI). However, Telford et al. (2004) demonstrated that, when the data set is small, no age-depth model provides a good fit to reality and that calculated confidence intervals are too optimistic.

Table 6 Linear regressions of SOM age-depth relationships of the Andosols, showing that the $95 \%$ confidence intervals of the slopes are overlapping.

\begin{tabular}{lllllr}
\hline Group & $\begin{array}{l}Y \text { intercept } \\
(\mathrm{cm})\end{array}$ & $\begin{array}{l}X \text { intercept } \\
(\text { cal AD) }\end{array}$ & Slope $^{\mathrm{a}} \pm 95 \% \mathrm{CI}$ & $R^{2}$ & $n^{\mathrm{b}}$ \\
\hline All soils & $49.77 \pm 3.645$ & 3135 & $-0.01588 \pm 0.00358$ & 0.87 & 16 \\
Western Cordillera & $47.57 \pm 4.606$ & 3097 & $-0.01536 \pm 0.00657$ & 0.91 & 6 \\
Eastern Cordillera & $51.16 \pm 5.462$ & 3186 & $-0.01606 \pm 0.00544$ & 0.85 & 10 \\
Forest & $62.95 \pm 5.647$ & 4292 & $-0.01467 \pm 0.00781$ & 0.87 & 6 \\
Páramo & $41.78 \pm 2.461$ & 2515 & $-0.01661 \pm 0.00248$ & 0.97 & 10 \\
\hline
\end{tabular}

${ }^{\text {a S}}$ Slope deviates significantly from zero $(p<0.005)$.

bSamples from organic horizon excluded from regressions.

The general increase of age with depth (slopes deviate significantly from zero) gives rise to 2 possible scenarios concerning the development of the current soil profile. The first scenario assumes that the current soil consists of only 1 tephra deposit. The observed age-depth relationship can then be explained by continuous burying of OM by younger OM much like in a peat bog. This scenario is possible with and without (shallow) bioturbation, because the zone of active bioturbation could shift upwards during SOM accumulation, resulting in a crude stratification. If bioturbation is present, a step-like curve would appear (for individual soil profiles) when applying smaller sampling distances. The second scenario assumes that the current soil consists of multiple tephra depositions. SOM is then intermittently buried by tephra, and the sedimentation rate mainly determines the agedepth relationship. Again, this scenario is possible with and without (shallow) bioturbation.

The slopes of the linear regressions for both cordilleras were surprisingly uniform (overlapping confidence intervals), suggesting that rates of tephra deposition and SOM incorporation have been similar. The similarity (overlapping confidence intervals) of the slopes according to vegetation type shows that the current vegetation type did not strongly influence the vertical OM distribution in the mineral horizons at the applied sampling distances. However, during soil profile development vegetation could have been different from today. The most notable influence of the current vegetation on soil profile development is the development of organic horizons (dated < cal AD 1957) in the forest. Although we did not include the organic samples in the regression, it is clear that the age-depth relationship in this layer is different, according to expectations. Additionally, the $y$ intercept of the linear regression of the forest soils (mineral horizons) is located at somewhat greater depth than the $y$ intercepts of the other regressions as a result of the relatively voluminous organic horizons.

Changes in SOM quantity due to fire may affect soil bulk density and therefore the age-depth relationship. However, Hofstede (1995) demonstrated that soil bulk density was not measurably affected by fire alone in Colombian páramos. As mentioned earlier, the dry bulk densities in the studied soils were similar for all samples. Additionally, the linear regressions of the age-depth relationship were similar for both cordilleras and similar for the current vegetation types, giving no reason to suspect that probable differences in, for example, fire frequency between cordilleras or vegetation types caused changes in the age-depth relationship. 


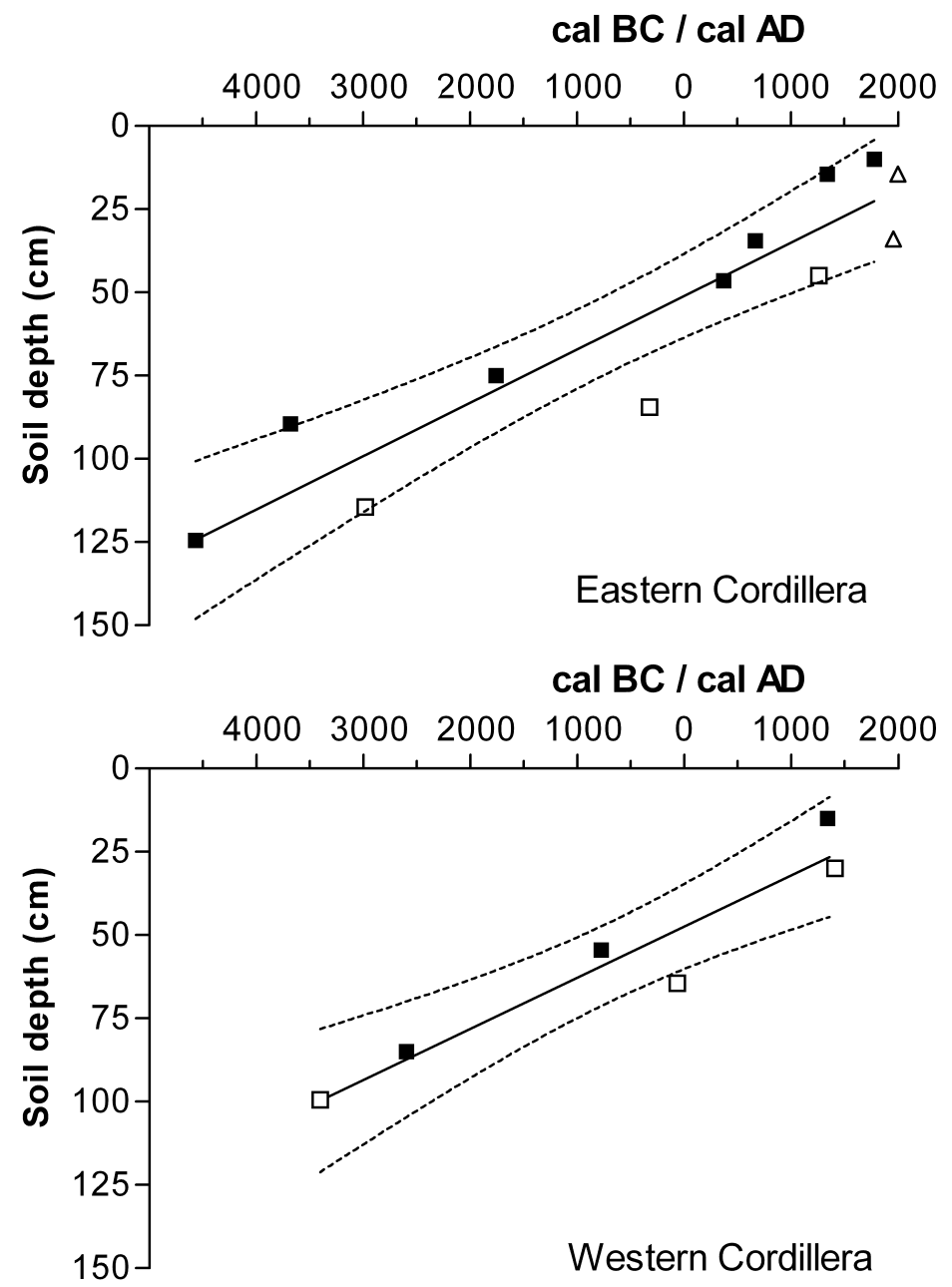

Figure 3 Age-depth relationships for the Eastern Cordillera and Western Cordillera; 95\% confidence interval (dashed lines) of linear regression (solid line) included. Regression equations presented in Table $6 . \mathbf{\square}=$ páramo; $\square=$ forest (mineral soil samples); $\triangle$ = forest (organic samples).

We conclude that the chronostratigraphy of the studied Andosols is very promising for use in paleoecological reconstructions, but more research concerning the tephra stratigraphy is necessary to explain the observed age-depth relationship. The presence of (shallow) bioturbation cannot be ruled out. We recommend applying higher resolution dating of the soil profiles to enable interpolation between dates.

\section{Comparison of Time Frame Soils and Peat Sequences}

Calibrated ${ }^{14} \mathrm{C}$ ages (of HA) of the peat cores are reported in Table 7. The calibrated ${ }^{14} \mathrm{C}$ ages of the Andosols were discussed in the previous section. Both the current soils (at least up to $1760 \mathrm{cal} \mathrm{BC}$ ) and the paleosols (at least up to $4565 \mathrm{cal} \mathrm{BC}$ ) were found to be of Holocene age. The time frames must be considered as a minimum because we did not date the exact events of tephra deposition or the base of the paleosol. Poulenard et al. (2003) reported similar ${ }^{14} \mathrm{C}$ ages of the bulk SOM fraction 
$<50 \mu \mathrm{m}$ of soils in northern Ecuador and dated the base of the paleosol to at least $7838 \mathrm{BP}$ ( $\sim 6683 \mathrm{cal}$ BC). Similarly, the 3 peat bogs are all of Holocene age, enabling verification of pollen records from soil by comparing them to pollen records from peat bogs. To enhance comparison, the tephra stratigraphy of the peat bogs should ideally be linked to the tephra stratigraphy of the soils. The peat sequences of Guandera and El Angel cover a larger time span (at least up to $6941 \mathrm{cal} \mathrm{BC}$ ) than the peat of Los Encinos (at least up to $809 \mathrm{cal} \mathrm{BC}$ ). This independent evidence supports the time frame we report for the studied Andosols.

Table 7 Calibrated ${ }^{14} \mathrm{C}$ ages (range and mean, year $\mathrm{AD} / \mathrm{BC}$ ) of the peat sequences.

\begin{tabular}{llll}
\hline & & \multicolumn{2}{c}{ Calibrated age } \\
\cline { 3 - 4 } Site & $\begin{array}{l}\text { Sample depth } \\
(\mathrm{cm})\end{array}$ & $\begin{array}{l}\text { Range } \\
(\text { cal AD/BC) }\end{array}$ & $\begin{array}{l}\text { Mean } \\
(\text { cal AD/BC) }\end{array}$ \\
\hline G8 & $146.0-147.0$ & cal BC 180-91 & cal BC 136 \\
G8 & $196.0-197.0$ & cal BC 5041-4939 & cal BC 4990 \\
G8 & $246.0-247$ & cal BC 6882-6827 & cal BC 6855 \\
A11 & $100.0-101.0$ & cal AD 379-434 & cal AD 407 \\
A11 & $160.0-161.0$ & cal BC 1776-1734 & cal BC 1755 \\
A11 & $222.0-222.5$ & cal BC 6438-6363 & cal BC 6401 \\
A2 & $66.0-66.5$ & cal AD 1522-1577 & cal AD 1550 \\
A2 & $176.5-177.0$ & cal AD 542-603 & cal AD 573 \\
A2 & $290.0-290.5$ & cal BC 820-797 & cal BC 809 \\
\hline
\end{tabular}

\section{CONCLUSIONS}

Our results show that in Andosols, ${ }^{14} \mathrm{C}$ dating of the HA fraction renders more accurate results than ${ }^{14} \mathrm{C}$ dating of the humin fraction, except for mineral soil samples just beneath a forest floor, where the opposite holds true. These results demonstrate that the accuracy of the ${ }^{14} \mathrm{C}$ age of a specific $\mathrm{OM}$ fraction depends on, e.g., soil properties and vegetation, underlining the necessity of tailor-made ${ }^{14} \mathrm{C}$ dating of soils. In the peat sequences, both OM fractions yield accurate results. The chronostratigraphy of SOM in the studied Andosols appears to be suitable for paleoecological research such as reconstruction of the natural position of the UFL, because age inversions and homogenization were lacking at the applied vertical sampling distances and age increased with depth. However, higher resolution dating of the soil profiles and more research concerning the tephra stratigraphy is necessary to be able to interpolate dates using the age-depth relationship. The time frame covered by the studied Andosols is similar to that of peat sequences nearby, enabling verification of the soil pollen records. With this research, we made an indispensable first step towards reconstruction of the natural position of the UFL in northern Ecuador.

\section{ACKNOWLEDGMENTS}

We gratefully acknowledge the Ecuadorian Ministerio del Ambiente for issuing the necessary permits for conducting our research in northern Ecuador and for supporting us in El Angel Ecological Reserve. Jatun Sacha and Grupo Randi Randi are thanked for allowing us to perform the research in Guandera Biological Station and Los Encinos Biological Station, respectively, and for helping us in the field. Ecopar is acknowledged for facilitating our research in the form of office assistance. Furthermore, we wish to thank Leo Hoitinga, Leen de Lange, Ton van Wijk and Niko de Wilde-deLigny for their assistance in the laboratory. Finally, we acknowledge Marcela Moscol, Antoine Cleef, Jan Sevink, Robert Hofstede, Emiel van Loon, Jan van Mourik, Klaas Nierop, Marjolein van 
der Linden, and Maartje van Meeteren for their valuable suggestions leading to the improvement of this manuscript. This research was funded by WOTRO (WAN 75-405) and generously sponsored by Fjällraven in the form of clothing and gear.

\section{REFERENCES}

Aerts-Bijma AT, van der Plicht J, Meijer HAJ. 2001. Automatic AMS sample combustion and $\mathrm{CO}_{2}$ collection. Radiocarbon 43(2A):293-8.

Bakker JGM, Salomons JB. 1989. A palaeoecological record of a volcanic soil sequence in the Nevado del Ruiz area, Colombia. Review of Palaeobotany and Palynology 60(1-2):149-63.

Barois I, Dubroeucq D, Rojas P, Lavelle P. 1998. Andosol-forming process linked with soil fauna under the perennial grass Mulhembergia macroura. Geoderma 86(3-4):241-60.

Birks HJB, Birks HH. 1980. Quaternary Palaeoecology. London: Edward Arnold. 289 p.

Bradley RS. 1999. Paleoclimatology: Reconstructing Climates of the Quaternary. 2nd edition. New York: Academic Press. 610 p.

Dalsgaard K, Odgaard BV. 2001. Dating sequences of buried horizons of podzols developed in wind-blown sand at Ulfborg, Western Jutland. Quaternary International 78(1):53-60.

Davidson DA, Carter S, Boag B, Long D, Tipping R, Tyler A. 1999. Analysis of pollen in soils: processes of incorporation and redistribution of pollen in five soil profile types. Soil Biology and Biochemistry 31(5): 643-53.

Ellenberg H. 1979. Man's influence on tropical mountain ecosystems in South America. Journal of Ecology 67(2):401-16.

Erdtman G. 1943. An Introduction to Pollen Analysis. Waltham, Massachusetts, USA: The Chronica Botanica Company. 239 p.

Food and Agricultural Organization of the United Nations [FAO]. 1990. Guidelines for Soil Description. Rome: FAO/ISRIC. 70 p.

Food and Agricultural Organization of the United Nations. 1998. World Reference Base for Soil Resources. Rome: FAO/ISRIC/ISSS. 91 p.

Gonzalez-Perez JA, Gonzalez-Vila FJ, Almendros G, Knicker H. 2004. The effect of fire on soil organic matter-a review. Environment International 30(6): 855-70.

Graphpad Software Inc. 1999. Graphpad Prism User's Guide Version 3. The fast, organized way to analyze and graph scientific data. San Diego, USA. 108 p.

Hetier JM, Guillet B, Brousse R, Delibrais G, Maury RC. 1983. ${ }^{14} \mathrm{C}$ dating of buried soils in the volcanic Chaine des Puys (France). Bulletin Volcanologique 46(2): 193-201.

Hofstede RGM. 1995. The effects of grazing and burning on soil and plant nutrient concentrations in Colombian páramo grasslands. Plant and Soil 173(1):111-32.
Keatinge TH. 1983. Development of pollen assemblage zones in soil profiles in southeastern England. Boreas 12:1-12.

Kovda IW, Lynn W, Williams D, Chichagova O. 2001. Radiocarbon age of Vertisols and its interpretation using data on gilgai complex in the north Caucasus. $R a$ diocarbon 43(2B):603-9.

Kristiansen S, Dalsgaard K, Holst MK, Aaby B, Heinemeier J. 2003. Dating of prehistoric burial mounds by ${ }^{14} \mathrm{C}$ analysis of SOM fractions. Radiocarbon $45(1)$ : 101-12.

Laegaard S. 1992. Influence of fire in the grass páramo vegetation of Ecuador. In: Balslev H, Luteyn JL editors. Páramo, an Andean Ecosystem Under Human Influence. London: Academic Press. p 151-70.

Lee KE, Foster RC. 1991. Soil fauna and soil structure. Australian Journal of Soil Research 29(6):745-75.

Manning MR, Lowe DC, Melhuish WH, Sparks RJ, Wallace G, Brenninkmeijer CAM, McGill RC. 1990. The use of radiocarbon measurements in atmospheric studies. Radiocarbon 32(1):37-58.

Meijer HAJ, van der Plicht J, Gislefoss JS, Nydal R. 1995. Comparing long-term atmospheric ${ }^{14} \mathrm{C}$ and ${ }^{3} \mathrm{H}$ records near Groningen, the Netherlands with Fruholmen, Norway and Izaña, Canary Island ${ }^{14} \mathrm{C}$ stations. Radiocarbon 37(1):39-50.

Meijer HAJ, Pertuisot MF, van der Plicht J. 2006. Highaccuracy measurements for atmospheric samples by AMS. Radiocarbon. This issue.

Mook WG, Streurman HJ. 1983. Physical and chemical aspects of radiocarbon dating. Pact 8(II.1):31-55.

Mook WG, van de Plassche O. 1986. Radiocarbon dating. In: van de Plassche O, editor. Sea-Level Research: A Manual for the Collection and Evaluation of Data. Norwich: Geo Books. p 525-60.

Moore PD, Webb JA, Collinson ME. 1991. Pollen Analysis. 2nd edition. Oxford: Blackwell Scientific Publications. 207 p.

Nierop KGJ, Buurman P. 1999. Insoluble organic matter fractions in incipient podzol B horizons: preservation of aliphatic biopolymers from roots. Humic Substances in the Environment 1(2):29-37.

Nierop KGJ, Buurman P, de Leeuw JW. 1999. Effect of vegetation on chemical composition of $\mathrm{H}$ horizons in incipient podzols as characterized by ${ }^{13} \mathrm{C}$ NMR and pyrolysis-GC/MS. Geoderma 90(1-2): $111-29$.

Nydal R, Lövseth K. 1983. Tracing bomb ${ }^{14} \mathrm{C}$ in the atmosphere 1962-1980. Journal of Geophysical Research 88:3621-42.

Orlova LA, Panychev VA. 1993. The reliability of radio- 
carbon dating buried soils. Radiocarbon 35(3):36977.

Pessenda LCR, Gouveia SEM, Aravena R. 2001. Radiocarbon dating of total soil organic matter and its comparison with ${ }^{14} \mathrm{C}$ ages of fossil charcoal. Radiocarbon 43(2B):595-601.

Poulenard JP, Podwojewski P, Herbillon AJ. 2003. Characteristics of non-allophanic Andosols with hydric properties from the Ecuadorian páramos. Geoderma 117(3-4):267-81.

Ramsay PM, Oxley ERB. 1996. Fire temperatures and postfire plant community dynamics in Ecuadorian grass páramo. Plant Ecology 124(2):129-44.

Reimer PJ, Baillie MGL, Bard E, Bayliss A, Beck JW, Bertrand CJH, Blackwell PG, Buck CE, Burr GS, Cutler KB, Damon PE, Edwards RL, Fairbanks RG, Friedrich M, Guilderson TP, Hogg AG, Hughen KA, Kromer B, McCormac G, Manning S, Bronk Ramsey C, Reimer RW, Remmele S, Southon JR, Stuiver M, Talamo S, Taylor FW, van der Plicht J, Weyhenmeyer CE. 2004. IntCal04 terrestrial radiocarbon age calibration, 0-26 cal kyr BP. Radiocarbon 46(3):1029-58.

Salomons JB. 1986. Paleoecology of volcanic soils in the Colombian Central Cordillera (Parque Nacional Natural de los Nevados) [PhD dissertation]. Dissertationes Botanicae 95, Cramer J, Berlin- Stuttgart. Amsterdam: Universiteit van Amsterdam. 212 p.

Scharpenseel HW, Becker-Heidmann P. 1992. Twentyfive years of radiocarbon dating soils: paradigm of erring and learning. Radiocarbon 34(3):541-9.

Schnitzer M. 1982. Organic matter characterization. In: Page A, editor. Methods of Soil Analysis. Part 2: Chemical and Microbiological Properties. Madison, Wisconsin: American Society of Agronomy, Soil Science Society of America. p 581-94.

Shoji SM, Nanzyo M, Dahlgren RA. 1993. Volcanic Ash Soils: Genesis, Properties and Utilization. New York:
Elsevier. 288 p.

Shore JS, Bartley DD, Harkness DD. 1995. Problems encountered with the ${ }^{14} \mathrm{C}$ dating of peat. Quaternary Science Reviews 14(4):373-83.

SPSS Inc. 2001. SPSS Base 11.0 User's Guide. Chicago, USA: SPSS Inc.

Stevenson FJ. 1994. Humus Chemistry. Genesis, Composition, Reactions. 2nd edition. New York: John Wiley. $496 \mathrm{p}$.

Telford RJE, Heegaard E, Birks HJB. 2004. All agedepth models are wrong: but how badly? Quaternary Science Reviews 23(1-2):1-5.

Torn MSS, Trumbore SE, Chadwick OA, Vitousek PM, Hendricks DM. 1997. Mineral control of soil organic carbon storage and turnover. Nature 389(6647):1703 .

van der Plicht J. 2005. WinCal25 [software program]. Groningen, the Netherlands, Center for Isotope Research, University of Groningen. URL: http:// www.cio.phys.rug.nl/HTML-docs/cio-us/frb10.htm.

van der Plicht J, Wijma S, Aerts AT, Pertuisot MH, Meijer HAJ. 2000. Status report: the Groningen AMS facility. Nuclear Instruments and Methods in Physics Research B 172(1-4):58-65.

van Mourik JM, Wartenbergh PE, Mook WG, Streurman HJ. 1995. Radiocarbon dating of palaeosols in aeolian sands. Mededelingen Rijks Geologische Dienst 52: 425-40.

Wang YR, Amundson R, Trumbore S. 1996. Radiocarbon dating of soil organic matter. Quaternary Research 45(3):282-8.

Wille M, Hooghiemstra H, Hofstede R, Fehse J, Sevink J. 2002. Upper forest line reconstruction in a deforested area in northern Ecuador based on pollen and vegetation analysis. Journal of Tropical Ecology 18(3):409-40. 